\title{
Electrochemical Corrosion Behavior of Carbon Steel and Hot Dip Galvanized Steel in Simulated Concrete Solution with Different pH Values
}

\author{
Wanchen XIE, Jiansan LI*, Yali LI \\ School of Mechanical and Automotive Engineering, South China University of Technology, Guangzhou, PR China \\ crossref http://dx.doi.org/10.5755/j01.ms.23.3.16675
}

Received 05 November 2016; accepted 21 January 2017

\begin{abstract}
Hot dip galvanizing technology is now widely used as a method of protection for steel rebars. The corrosion behaviors of Q235 carbon steel and hot galvanized steel in a $\mathrm{Ca}(\mathrm{OH})_{2}$ solution with a $\mathrm{pH}$ from 10 to 13 was investigated by electrode potential and polarization curves testing. The results indicated that carbon steel and hot galvanized steel were both passivated in a strong alkaline solution. The electrode potential of hot dip galvanized steel was lower than that of carbon steel; thus, hot dip galvanized steel can provide very good anodic protection for carbon steel. However, when the $\mathrm{pH}$ value reached 12.5, a polarity reversal occurred under the condition of a certain potential. Hot dip galvanized coating became a cathode, and the corrosion of carbon steel accelerated. The electrochemical behaviors and passivation abilities of hot dip galvanized steel and carbon steel were affected by $\mathrm{pH}$. In the higher $\mathrm{pH}$ solutions, passivation occurred with ease.

Keywords: carbon steel, galvanized steel, $\mathrm{pH}$ values, electrochemical test.
\end{abstract}

\section{INTRODUCTION}

Reinforcement concrete is widely used in modern architecture. However, it is being found that reinforced concrete structures lose efficiency too quickly, especially in corrosion media or dry-wet-cycle conditions, which can cause serious losses. At present, the engineering industry is paying more attention to this particular issue [1 -4].

Concrete has pores in it, and in the early stage, the main ingredient of a concrete pore solution is a saturated $\mathrm{Ca}(\mathrm{OH})_{2}$ solution, and steel has a compact passivated layer. Carbonation and $\mathrm{Cl}$ ions [4-6] are two of the most serious contributors to the reinforcement corrosion problem. A neutralization reaction occurs when $\mathrm{CO}_{2}$ passed capillary pores of concrete are combined with $\mathrm{Ca}(\mathrm{OH})_{2}$ in the concrete pore solution, which then creates $\mathrm{CaCO}_{3}$. This whole process is referred to as carbonation. With the carbonation process, the $\mathrm{pH}$ of the concrete pore solution changes, which then influences passive film formation on steel bars. This result ultimately increases the possibility of reinforcement corrosion.

There are two main methods for the corrosion protection of steel bars. One is to improve concrete performance, such as adding an inhibitor or water reducer that coats the surface of the concrete. The other is to improve the performance of the steel bar, such as using stainless steel bars with anti-corrosion properties, and applying an epoxy coating or metal coating to the surface. One type of metal coating is hot dip galvanized coating. This simple process has become an effective means of preventing the corrosion of reinforced steel in concrete. During the galvanizing, a metallurgical reaction occurs when the zinc solution comes into contact with the reinforcement; then, a tough, non-corrosive coating forms, which insulates the steel from the outside environment. At

\footnotetext{
${ }^{*}$ Corresponding author. Tel.: +8620-87114574

E-mail address: jsli@scut.edu.cn (J. Li)
}

the same time, the zinc coating can be used as a sacrificial anode to provide steel substrate electrochemical protection. Furthermore, the addition of $\mathrm{Ni}, \mathrm{Mn}, \mathrm{Al}, \mathrm{Mg}$, and rare earth alloy elements in the zinc bath could further improve and optimize the corrosion resistance of zinc coating [7]. Topuz [8] have discussed the time of corrosion initiation of hot dip galvanized coating on reinforcement corrosion through the comparisons of the coated and uncoated concrete specimens after accelerated corrosion. The comparison can be used to judge whether the hot dip galvanized coating still has protective effect under different conditions.

There are many methods for studying the corrosion process of steel bars in concrete samples. The electrochemical method has a relatively mature theoretical framework as well as uncomplicated sample and equipment preparation. The aim of this work is to study the protective effect of hot dip galvanizing on carbon steel and the corrosion behavior of carbon steel as well as hot dip galvanized steel in a $\mathrm{Ca}(\mathrm{OH})_{2}$ simulated solution with a $\mathrm{pH}$ from 10 to 13 , through analysis of open-circuit potential (OCP) and polarization curves.

\section{EXPERIMENTAL}

\subsection{Materials and solutions}

Hot dip galvanized steel and Q235 carbon steel samples, with a size of $30 \mathrm{~mm} \times 40 \mathrm{~mm} \times 1 \mathrm{~mm}$, were prepared. Prior to testing, the specimens were degreased with acetone and alcohol successively in an ultrasonic bath for $15 \mathrm{~min}$, immersed in $1 \mathrm{wt} . \% \mathrm{NaOH}$ solution around $60{ }^{\circ} \mathrm{C}$ for $10 \mathrm{~min}$, rinsed with hot water and room temperature water successively, and dried in flowing air. Than the specimens were encapsulated by epoxy resin with a surface of $10 \mathrm{~mm} \times 10 \mathrm{~mm}$.

Fresh wet concrete shows a $\mathrm{pH}$ between 12.5 and 13.3 [9]. Studies have shown that the pore solution extracted 
from the actual non-carbonized cement is essentially a mixed solution of $\mathrm{NaOH}$ and $\mathrm{KOH}$ [10]. Page et al. [11] determined that when the simulated concrete pore solution containing a mix of $\mathrm{NaOH}$ and $\mathrm{KOH}$ has a $\mathrm{pH}$ of above 12.6, it does not have a buffering effect on the $\mathrm{pH}$. This means some of the common reaction will easily reduce the high alkalinity of the solution. In view of actual reinforcement use, the $\mathrm{pH}$ of noncarbonated cement was more inclined to the $\mathrm{pH}$ buffering range provided by a $\mathrm{Ca}(\mathrm{OH})_{2}$ solution (about $\mathrm{pH}$ 12.5) [12]. Numerous foreign studies on the influence of reinforcement corrosion adopted a saturated $\mathrm{Ca}(\mathrm{OH})_{2}$ solution as a simulated concrete pore (SCP) solution [13,14], and its initial $\mathrm{pH}$ was 12.5. With the carbonation process, the $\mathrm{pH}$ of the concrete pore solution decreases. When the $\mathrm{pH}$ drops below 10 , the corrosion rate of reinforcing steel increases quickly [1].

So, saturated $\mathrm{Ca}(\mathrm{OH})_{2}$ solution was prepared with analytically pure $\mathrm{Ca}(\mathrm{OH})_{2}$ and deionized water. Four batches of SCP solutions were prepared with $\mathrm{pH}$ values of $10,11,12$, and 13 by diluting or adding a $\mathrm{NaOH}$ solution to the saturated $\mathrm{Ca}(\mathrm{OH})_{2}$ solution.

\subsection{Experiments}

The electrochemical measurements were made at room temperature using a EG\&G-PAR263A electrochemical workstation. The OCP data was recorded for $3600 \mathrm{~s}$ at a rate of $10 \mathrm{~s}$ after working electrode samples were immersed in SCP solutions of $\mathrm{pH} 10,11,12,12.5$, and 13 successively [15]. A three-electrode system was used with SCE as the reference electrode, a platinum electrode as the auxiliary electrode, and samples with exposed areas of $1 \mathrm{~cm}^{2}$ as the working electrode. Based on the electrode potential of the standard hydrogen electrode, the electrode potential of SCE was $+0.2415 \mathrm{~V}$. The potentiodynamic polarization curves were measured at a scan rate of $1 \mathrm{mV} / \mathrm{s}$ $[16,17]$.

\section{RESULTS AND DISCUSSION}

\subsection{Open-circuit potential}

Fig. 1 shows the OCP curves of the samples. The OCP of carbon steel remained values of $-500 \mathrm{mV}_{\mathrm{SCE}}$ to $-200 \mathrm{mV}_{\mathrm{SCE}}$ range. According to the E-pH diagram of the $\mathrm{Fe}-\mathrm{H}_{2} \mathrm{O}$ system, carbon steel was in the passive region and covered with $\mathrm{Fe}_{2} \mathrm{O}_{3}$ or $\mathrm{Fe}_{3} \mathrm{O}_{4}$, which could protect carbon steel under an alkaline condition. However, some potentially harmful ions, such as $\mathrm{Cl}^{-}$and $\mathrm{SO}_{4}{ }^{2-}$, can easily destroy the passive film, thereby allowing the corrosion of carbon steel to accelerate. Likewise, the OCP of the hot dip galvanized steel was held at a relatively stable value in the range of $-1500 \mathrm{mV}_{\mathrm{SCE}}$ to $-750 \mathrm{mV}_{\mathrm{SCE}}$. According to the E-pH diagram of the $\mathrm{Zn}-\mathrm{H}_{2} \mathrm{O}$ system, the hot dip galvanized steel was in the passive region, covered with $\mathrm{Zn}(\mathrm{OH})_{2}$ passive film.

Table 1 shows the electrode potentials of samples in SCP solution. As shown in Table 1, the stable potential of the hot dip galvanized steel was far lower than that of Q235 carbon steel with $\mathrm{pH}$ ranging from 10 to 13 . This means hot dip galvanizing supplies sacrificial anode protection for Q235 carbon steel in an alkaline solution. In the SCP solution of $\mathrm{pH} \mathrm{12,} \mathrm{the} \mathrm{open} \mathrm{circuit} \mathrm{potential} \mathrm{of}$ Q235 carbon steel reached a maximum, while the hot dip galvanized steel reached a minimum $[18-20]$. At this $\mathrm{pH}$, the potential gap reached a maximum, and hot dip galvanizing had the best protective effect on the matrix.

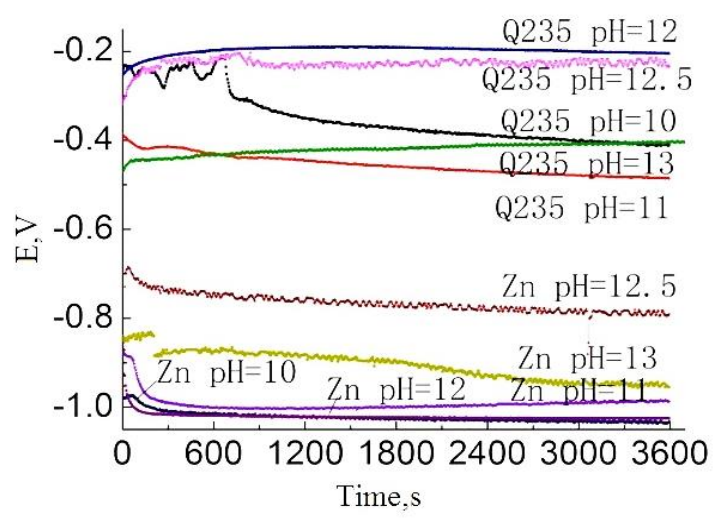

Fig. 1. OCP values of Q235 carbon steel and hot dip galvanized steel in SCP solution

Table 1. Electrode potentials of Q235 carbon steel and hot dip galvanized steel in SCP solutions

\begin{tabular}{|c|c|c|c|}
\hline $\mathrm{pH}$ & $\mathrm{E}_{\mathrm{Q} 235}$ & Egalvanized & EQ235- Egalvanized \\
\hline $\mathrm{pH}=10$ & $-0.411 \mathrm{~V}$ & $-1.035 \mathrm{~V}$ & $0.624 \mathrm{~V}$ \\
\hline $\mathrm{pH}=11$ & $-0.485 \mathrm{~V}$ & $-0.987 \mathrm{~V}$ & $0.502 \mathrm{~V}$ \\
\hline $\mathrm{pH}=12$ & $-0.205 \mathrm{~V}$ & $-1.025 \mathrm{~V}$ & $0.820 \mathrm{~V}$ \\
\hline $\mathrm{pH}=12.5$ & $-0.223 \mathrm{~V}$ & $-0.792 \mathrm{~V}$ & $0.569 \mathrm{~V}$ \\
\hline $\mathrm{pH}=13$ & $-0.393 \mathrm{~V}$ & $-0.955 \mathrm{~V}$ & $0.562 \mathrm{~V}$ \\
\hline
\end{tabular}

\subsection{Potentiodynamic polarization curves}

The potentiodynamic polarization curves of Q235 carbon steel in SCP solution are shown in Fig.2. Under pH 10 and 11, the Q235 carbon steel experienced an active dissolution region and passivation region. Under $\mathrm{pH} 12$, 12.5 , and 13, Q235 carbon steel experienced an active dissolution region, passivation region, and transpassive region, successively, and the passivation current was around $7.75 \times 10-6 \mathrm{~A} / \mathrm{cm}^{2}$. Under $\mathrm{pH} 13$, the carbon steel turned into a passive state after transient active dissolution, the associated passivation potential range was $-0.393 \mathrm{~V}$ to $0.591 \mathrm{~V}$, which is twice as large as the range at $\mathrm{pH} 12$ and 12.5. In the active dissolution region, the corrosion current increased rapidly with increasing electric potential. According to the E-pH diagram of the $\mathrm{Fe}-\mathrm{H}_{2} \mathrm{O}$ system, it is speculated that the carbon steel was dissolved by the following equation:

$\mathrm{Fe} \rightarrow \mathrm{Fe}^{2+}+2 \mathrm{e}^{-}$.

For the passivation process, the reaction may be represented by the following equation:

$2 \mathrm{Fe}^{2+}+3 \mathrm{H}_{2} \mathrm{O} \rightarrow \mathrm{Fe}_{2} \mathrm{O}_{3}+6 \mathrm{H}^{+}+2 \mathrm{e}^{-}$.

When it turned into a transpassive region, the anodic current density increased rapidly with the increase in electric potential, and ferric iron may have formed with an oxygenation reaction [17]. 


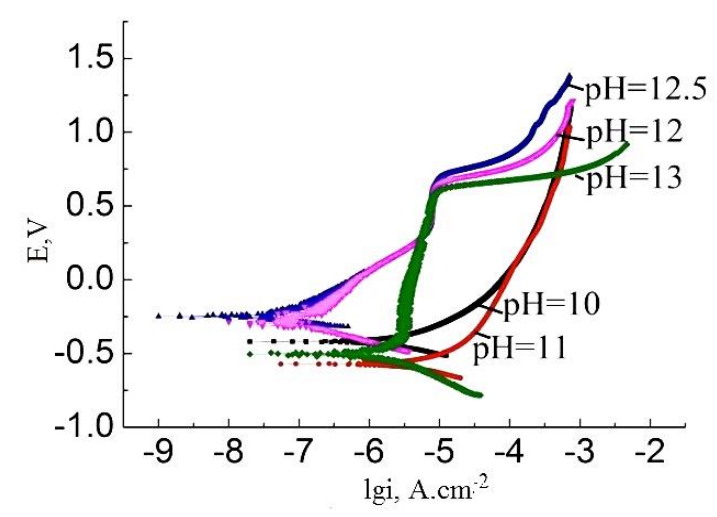

Fig. 2. Potentiodynamic polarization curves of Q235 carbon steel in SCP solution

According to electrochemistry principles, the corrosion rate of metal is proportional to the corrosion current density $\left(i_{\text {corr }}\right)$. It can be seen from Fig. 2 that the more alkaline the SCP solutions are, the smaller the corrosion current and corrosion rate are. Carbon steel is easier to turn into passive state with good corrosion resistance [21].

The potentiodynamic polarization curves of hot dip galvanized steel in SCP solution are shown in Fig. 3.

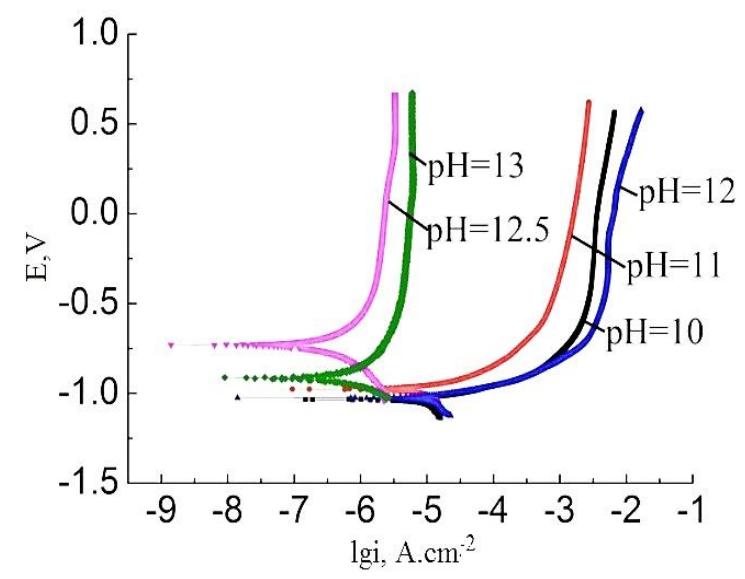

Fig. 3. Potentiodynamic polarization curves of hot dip galvanized steel in SCP solution

From Fig. 3, it is clear that for the hot dip galvanized steel, the self-corrosion potential corresponds to the OCP. The potential reached a minimum at $\mathrm{pH} 12.5$ and a maximum at $\mathrm{pH} 10$. Under $\mathrm{pH} 10$ to 13 , the hot dip galvanized steel experienced an active dissolution region and passivation region, successively. In the passivation region, the current changes with the potential are not clear; this indicates that the passive film has protective effects. Under $\mathrm{pH} 10$ to 12 , the polarization current continuously increased, and the active dissolution region was long. When the $\mathrm{pH}$ was 12.5 and 13 , the polarization curves of the hot dip galvanized steel had large differences from pH 10 to 12 , which exhibited a short dissolution active region and an obvious self-passivation phenomenon. With an increase in $\mathrm{pH}$, the passivation current of the hot dip galvanized steel demonstrated instability. It decreased first and then increased ( $\mathrm{pH}$ of 12), before experiencing a significant reduction ( $\mathrm{pH}$ of 12.5), and finally, there was a small increase ( $\mathrm{pH}$ of 13). Ren Pengying [22] noticed that in a saturated $\mathrm{Ca}(\mathrm{OH})_{2}$ solution of $\mathrm{pH} 12.6$, a zinc coating on galvanized steel generated corrosion products $\mathrm{Zn}(\mathrm{OH})_{2}$ and $\mathrm{ZnO}$, which has an instability state.
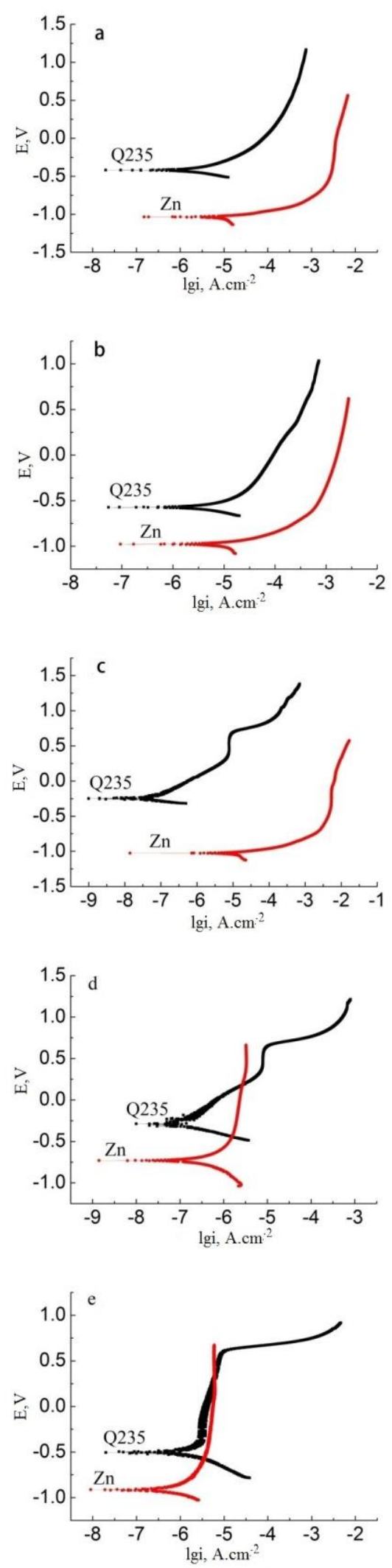

Fig. 4. Potentiodynamic polarization curves of hot dip galvanized steel and Q235 carbon steel in SCP solutions

Through experiments, Liu Shuan [23] observed that when the $\mathrm{pH}$ value was between 12 and 12.7 , zinc coating passivation is not stable. The corrosion products in the 
$\mathrm{Ca}(\mathrm{OH})_{2}$ solution were $\mathrm{ZnO}, \quad \mathrm{Zn}(\mathrm{OH})_{2}, \quad$ and $\mathrm{Zn}_{5}(\mathrm{OH})_{6}\left(\mathrm{CO}_{3}\right)_{2}$. When $\mathrm{pH}$ was above 12.7 , zinc coating passivation became stable. It can be speculated that in a strong alkaline environment, the surface electrochemical state of the hot dip galvanized steel was highly affected by $\mathrm{pH}$ value, which relates to the dissolution and generation of the corrosion products. On the whole, the higher $\mathrm{pH}$ of the SCP solution is, the smaller the passivation current of hot dip galvanized steels, the larger the passivation region, and the stronger the corrosion resistance. For example, in a SCP solution of $\mathrm{pH} 12.5$, the self-corrosion potential of hot dip galvanized steel reached a maximum, and the corrosion current reached a minimum [24-26]. Fig. 4 gives potentiodynamic polarization curves, which dynamically show the electrochemical behavior of the hot galvanized steel on carbon steel. As Fig. $4 \mathrm{a}-\mathrm{c}$ shows, the electric currents of the hot dip galvanized steel were higher than those of Q235 carbon steel under the same potential in the SCP solution of $\mathrm{pH} 10$ to 12 . In the same solution, the hot dip galvanized coating was always an anode of the galvanic cell and ensures sacrificial protection for the matrix. At $\mathrm{pH} 12$, the current achieved a maximum, and the protective effect was best, which is consistent with the preceding discussion. In Fig. $4 \mathrm{~d}$ and e, under $\mathrm{pH} 12.5$ and 13 , the anodic polarization curves of Q235 carbon steel and hot galvanized steel intersect at $0.179 \mathrm{~V} ; 2.56 \times 10^{-}$ ${ }^{6} \mathrm{~A} / \mathrm{cm}^{2}$ and $0.334 \mathrm{~V} ; 6.08 \times 10^{-6} \mathrm{~A} / \mathrm{cm}^{2}$ respectively. When the corrosion current of the hot dip galvanized steel was higher than that of Q235 carbon steel, hot dip galvanized coating was always an anode of the galvanic cell and supplied sacrificial protection for matrix. Beyond intersection, anodic reversal would occur. This means the hot dip galvanized coating would be a cathode of the galvanic cell, and matrix corrosion may be accelerated. Fig. 4 indicates that the sacrificial anode protection using hot dip galvanizing was not absolute in an alkaline environment. When alkaline solution has $\mathrm{pH}$ higher than 12.5 , anodic reversal may occur, and corrosion may be accelerated.

\section{CONCLUSIONS}

Carbon steel and hot dip galvanized steel were both passivated in a strong alkaline solution. The electrode potential of the hot dip galvanized steel was lower than that of carbon steel; therefore, hot dip galvanized steel provides very good anodic protection for carbon steel. However, when the $\mathrm{pH}$ value reached 12.5, anodic reversal occurred under the condition of a certain potential. Hot dip galvanized coating becomes cathode and the corrosion of carbon steel was accelerated. The electrochemical behavior and passivation of the hot dip galvanized steel and carbon steel are affected by $\mathrm{pH}$. In the higher $\mathrm{pH}$ solutions, passivation occurred with ease.

\section{REFERENCES}

1. Huet, B., L'Hostis, V., $\quad$ Miserque, F., Idrissi, H. Electrochemical Behavior of Mild Steel in Concrete: Influence of $\mathrm{pH}$ and Carbonate Content of Concrete Pore Solution Electrochimica Acta 51 (1) 2005: pp. 172 - 180. https://doi.org/10.1016/j.electacta.2005.04.014
2. Hamann, C.H., Hamnett, A., $\quad$ Vielstich, W. Electrochemistry. Wiley-VCH, 2007: pp. 170-171.

3. Lin, C., Zhao, Q., Nan, D.U., Zhang, S.P., Feng, C.J. Corrosion Measurement of Carbon Steel in Simulated Concrete Solution Surface Technology 39 (3) 2010: pp. 404-47.

4. Shunmugam, M.S., $\quad$ Philip, P.K., Gangadhar, A. Improvement of Wear Resistance by Edm with Tungsten Carbide p/m Electrode Wear 171 (94) 1994: pp. 1-5. https://doi.org/10.1016/0043-1648(94)90340-9

5. Kong, G., Chen, J.L., Jin-Tang, L.U. Effects of pH Value of Saturated $\mathrm{Ca}(\mathrm{OH}) \_2$ Solution on CaHZn Coating of Hot Dip Galvanized Steel Journal of Materials Engineering 30 (9) 2010: pp. 74-79.

6. Mokaddem, M., Volovitch, P., Ogle, K. The Anodic Dissolution of Zinc and Zinc Alloys in Alkaline Solution. I. Oxide Formation on Electrogalvanized Steel Electrochimica Acta 55 (27) 2010: pp. 7867-7875. https://doi.org/10.1016/j.electacta.2010.02.020

7. Sun, H.Y., Zang, B.N., Liu, S., Sun, L.J., Fan, H.J. Effects of $\mathrm{Zn}(\mathrm{OH})_{2}$ on Corrosion Behavior of Hot Dipped $\mathrm{Zn}$ Coating in Freshwater Advanced Materials Research 399-401 2011: pp. $152-155$.

https://doi.org/10.4028/www.scientific.net/AMR.399401.152

8. Topuz, P., Aydin O. Effect of Hot Dip Galvanized Coating on the Corrosion Resistance of the Eternal Surface of Reinforcement Steel Materialprufung 58 (2) 2016: pp. $248-253$. https://doi.org/10.3139/120.110835

9. American Concrete Institute. Protection of Metals in Concrete against Corrosion Report No. ACI 222R-01 2001.

10. Mammoliti, L.T., Brown, L.C., Hansson, C.M., Hope, B.B. The Influence of Surface Finish of Reinforcing Steel and pH of the Test Solution on the Chloride Threshold Concentration for Corrosion Initiation in Synthetic Pore Solutions Cement \& Concrete Research 26(4) 1996: pp. $545-550$.

https://doi.org/10.1016/0008-8846(96)00018-X

11. Page, C.L., Treadaway, K.W.J. Aspects of the Electrochemistry of Steel in Concrete Nature 297 (5862) 1982: pp. $109-115$. https://doi.org/10.1038/297109a0

12. Liu, R., Jiang, L., Xu, J., Xiong, C., Song, Z. Influence of Carbonation on Chloride-induced Reinforcement Corrosion in Simulated Concrete Pore Solutions Construction \& Building Materials 56 (4) 2014: pp. 16-20. https://doi.org/10.1016/j.conbuildmat.2014.01.030

13. Torres-Luque, M., Bastidas-Arteaga, E., Schoefs, F., Sánchez-Silva, M., Osma, J.F. Non-destructive Methods for Measuring Chloride Ingress into Concrete: State-of-theart and Future Challenges Construction \& Building Materials 68 (4) 2014: pp. $68-81$. https://doi.org/10.1016/j.conbuildmat.2014.06.009

14. Mohamed, N., Boulfiza, M., Evitts, R. Corrosion of Carbon Steel and Corrosion-resistant Rebars in Concrete Structures under Chloride Ion Attack Journal of Materials Engineering \& Performance 22 (3) 2010: pp. 787-795. https://doi.org/ 10.1007/s11665-012-0314-0

15. Corderoy, D., Herzog, H. Passivation of Galvanized Reinforcement by Inhibitor Anions Corrosion of Reinforcing Steel In Concrete, Symposium 1980: pp. $88-90$. https://doi.org/10.1520/STP27474S 
16. Geng, G. Comparison of Electrochemical Measurements for Steel Corrosion in Simulated Concrete Pore Solution Dongnan Daxue Xuebao 41 (2) 2011: pp. 382-386. https://doi.org/10.3969/j.issn.1001-0505.2011.02.032

17. Jiang, N., Shen, Y.G., Zhang, H.J., Bao, S.N., Hou, X.Y. Superhard Nanocomposite Ti-Al-Si-N Films Deposited by Reactive Unbalanced Magnetron Sputtering Materials Science \& Engineering B 135 (1) 2006: pp. 1-9. https://doi.org/10.1016/j.mseb.2006.06.043

18. Suh, N.P. Tribophysics Journal of Tribology 1986: pp. 416-424.

19. Sistonen, E., Cwirzen, A., Puttonen, J. Corrosion Mechanism of Hot-dip Galvanised Reinforcement Bar in Cracked Concrete Corrosion Science $50(12)$ 2008: pp. 3416-3428. https://doi.org/10.1016/j.corsci.2008.08.050

20. Vera, R., Venegas, R., Carvajal, A.M., Corvo, F., Pérez, T. Performance of Carbon Steel and Galvanized Steel in Reinforced Concrete Structures After Accelerated Carbonation International Journal of Electrochemical Science 7 (11) 2012: pp. 10722-10734.

21. Hime, W.G., Machin, M.G. Performance Variances of Galvanized Steel in Mortar and Concrete Corrosion Houston Tx- 49 (10) 1993: pp. 858-860.

\section{https://doi.org/10.5006/1.3316010}

22. Ren, P.Y., Ji-Quan, H.E. Electrochemical Behavior of Zinc Alloy Anode in $\mathrm{Ca}(\mathrm{OH}) \_2$ Solutions of Different $\mathrm{pH}$ Electrochemistry 13 (04) 2007: pp. 398 -402.

23. Liu, S., Sun, H.Y., Sun, L.J. Effects of $\mathrm{pH}$ Values and Temperature on the Electrochemical Corrosion Behavior of Galvanized Steel in Simulated Rust Layer Solution Journal of Functional Materials 44 (6) 2013: pp. 858-830.

24. Boyd, W.K., Tripler, A.B. Corrosion of Reinforcing Steel Bars in Concrete Materials Protection 7 (10) 1968: pp. $40-47$.

25. Tan, Z.Q., Hansson, C.M. Effect of Surface Condition on the Initial Corrosion of Galvanized Reinforcing Steel Embedded in Concrete Corrosion Science 50 (9) 2008: pp. 2512-2522. https://doi.org/10.1016/j.corsci.2008.06.035

26. Yadav, A.P., Katayama, H., Noda, K., Masuda, H., Nishikata, A., Tsuru, T. Effect of Fe-Zn Alloy Layer on the Corrosion Resistance of Galvanized Steel in Chloride Containing Environments Corrosion Science 49 (9) 2007: pp. 3716-3731. https://doi.org/10.1016/j.corsci.2007.03.039 